\title{
UJI EFEKTIVITAS LARUTAN MADU SEBAGAI ANTIBAKTERI TERHADAP PERTUMBUHAN Staphylococcus aureus DAN Pseudomonas aeruginosae DENGAN METODE DISK DIFFUSION
}

\author{
Yuliati $^{1}$ \\ ${ }^{1}$ Fakultas Kedokteran UIN Syarif Hidayatullah Jakarta \\ Email : yuli_bahruddin70@yahoo.com
}

\begin{abstract}
ABSTRAK
Madu merupakan salah satu pengobatan tradisional yang dapat digunakan di masyarakat untuk penanganan luka sejak berabad yang lalu, karena madu memiliki efek antibakteri diantaranya madu memiliki osmolaritas yang tinggi, kandungan hidrogen peroksida, $\mathrm{pH}$ yang rendah dan memiliki aktivitas yang rendah. Mekanisme antibakteri diantaranya $\mathrm{pH}$ madu yang bersifat asam yang berkisar antara 3,24,5 ssehingga akan menghambat metabolisme bakteri Gram negatif dan positif dengan menghambat metabolisme bakteri akan menyebabkan bakteri mudah mengalami lisis, ssehingga akhirnya dapat menghambat pertumbuhan bakteri. Fungsi madu dapat digunakan sebagai pengobatan luka, kontrol gula darah pasien diabetes, antioksidasi, mencegah radang lapisan luar disekitar mulut pada pengobatan sinar laser pasien kanker, mengobati radang saluran cerna, serta sebagai bahan produk kecantikan, rambut dan kulit. Penelitian ini dilakukan untuk mengetahui perbandingan efektivitas larutan madu terhadap pertumbuhan bakteri Staphylococcus aureus dan Pseudomonas aeruginosae dengan berbagai konsentrasi $10^{5} \mathrm{ppm}, 10^{6} \mathrm{ppm}, 5 \times 10^{6} \mathrm{ppm}, 10^{7} \mathrm{ppm}$, dan $10^{8} \mathrm{ppm}$ dengan metode difusi sumur. Berdasarkan hasil penelitian dari hasil pengukuran zona hambat dari kuman Staphylococcus aureus termasuk dalam kategori lemah dengan konsentrasi $10^{6} \mathrm{ppm} .5 \times 10^{6} \mathrm{ppm}, 10^{7} \mathrm{ppm}$, dan $10^{8} \mathrm{ppm}$ didapatkan zona hambat dengan rata-rata diameter sebesar $6,5 \mathrm{~mm}, 10,5 \mathrm{~mm}, 12 \mathrm{~mm}$, dan $14,7 \mathrm{~mm}$. Sedangkan untuk kuman Pseudomonas aeruginosae dengan konsentrasi $10^{6} \mathrm{ppm}, 5 \times 10^{6} \mathrm{ppm}, 10^{7} \mathrm{ppm}$ didapatkan zona hambat sebesar $6 \mathrm{~mm}, 8,5 \mathrm{mmm}$, dan 9,5 $\mathrm{mmm}$ termasuk dalam kategori rendah, dan konsentrasi $10^{8} \mathrm{ppm}$ didapatkan zona hambat sebesar 10,5 mm termasuk dalam kategori lemah. Kesimpulan dari penelitian efektivitas antibakteri larutan madu lebih efektif terhadap kuman Staphylococcus aureus dibandingkan terhadap kuman Pseudomonas aeruginosae, walaupun perbedaannya tidak signifikan.
\end{abstract}

Kata kunci : Madu; Metode Difusi; Staphylococcus aureus; Pseudomonas aeruginosae

\begin{abstract}
Honey is one of the traditional medicine that can be used in the community for wound treatment since centuries ago. Honey has an antibacterial effect, due to its high osmolarity, hydrogen peroxide content, low $\mathrm{pH}$ and low activity. The $\mathrm{pH}$ of honey is acidic (ranges about 3.2-4.5), inhibits the metabolism of Gram negative and positive bacteria, in consequence would be bacterial metabolism inhibition. This condition would lead to bacterial lysis. Honey can be used as wound treatment, controls blood sugar in diabetes patient's, antioxidants, prevents inflammation outer layer surrounding the mouth of the laser beam treatment of cancer patients, treats gastrointestinal inflammation, as well as the material beauty products, hair and skin. This study was conducted to determine the comparative effectiveness of honey solution on the growth of Staphylococcus aureus and Pseudomonas aeruginosae with various concentrations of $10^{5} \mathrm{ppm}, 10^{6} \mathrm{ppm}, 5 \times 10^{6} \mathrm{ppm}, 10^{7} \mathrm{ppm}$, and $10^{8} \mathrm{ppm}$ by well diffusion method. According to the MIC result on $S$.aureus, its is included in weak category, with an average diameter 6.5 $\mathrm{mm}, 10.5 \mathrm{~mm}, 12 \mathrm{~mm}$, and $14.7 \mathrm{~mm}$ on $10^{6} \mathrm{ppm}, 5 \times 10^{6} \mathrm{ppm}, 10^{7} \mathrm{ppm}$, and $10^{8} \mathrm{ppm}$, respectively. Based
\end{abstract}


on the MIC result on Pseudomonas aeruginosae, it also included in weak category, with an average diameter $6 \mathrm{~mm}, 8.5 \mathrm{um}, 9.5 \mathrm{~mm}, 10.5 \mathrm{~mm}$ on $10^{6} \mathrm{ppm}, 5 \times 10^{6} \mathrm{ppm}$ on $10^{6} \mathrm{ppm}, 5 \times 10^{6} \mathrm{ppm}, 10^{7} \mathrm{ppm}$, and $10^{8} \mathrm{ppm}$, respectively. This study concluded that antibacterial from honey solution is more effective against Staphylococcus aureus than Pseudomonas aeruginosae, although there are no significantly difference.

Keywords : Diffusion Methods; Honey; Staphylococcus aureus; Pseudomonas aeruginosae

\section{PENDAHULUAN}

Sekitar $80 \%$ penduduk di dunia menggunakan pengobatan tradisional untuk penyembuhan dan perawatan kesehatan. ${ }^{1}$ Madu merupakan salah satu pengobatan tradisional digunakan di masyarakat untuk penanganan luka dan sudah dikenal sejak berabad yang lalu.

Madu adalah cairan kental yang diproduksi oleh lebah madu dari nektar bunga dan diduga berkhasiat dalam menyembuhkan berbagai jenis penyakit, antioksidan, antiinflamasi, obat saluran respirasi, gangguan mata, diabetes mellitus, dan juga dapat mendukung pertumbuhan mikroba probiotik. Beberapa penelitian yang telah dilakukan menunjukan bahwa madu dapat digunakan sebagai antimikroba pada luka termasuk luka pasca operasi. Penelitian yang dilakukan terhadap pasien pasca operasi pada luka yang tidak berhasil disembuhkan oleh antibiotik intravena, dengan mengoleskan madu 5-10 mL dua kali sehari memperlihatkan terjadinya penyembuhan luka pada 5 hari pemakaian. ${ }^{2}$

Madu bersifat antimikroba karena tersusun atas beberapa molekul gula seperti glukosa dan fruktosa serta sejumlah mineral dan vitamin. Dibawah ini adalah kandungan umum madu murni terdiri dari air $(17,0 \%)$, fruktosa $(38,5 \%)$, glukosa $(31,5 \%)$, maltosa $(7,2 \%)$, karbohidrat $(4,2 \%)$, sukrosa $(1,5 \%)$, enzim, mineral, vitamin $(0,5 \%)$, energi kalori/100 gram/294,0\%. (Hotnida, 2002). Menurut Puspitasari kemampuan madu bersifat sebagai antibakteri diduga karena madu memiliki osmolaritas yang tinggi, kandungan hydrogen peroksida, $\mathrm{pH}$ yang rendah, dan memiliki aktivitas air yang rendah. Selain itu, madu juga memiliki aktivitas senyawa antibakteri terutama pada bakteri Gram(+), yakni bakteri S. aureus dan B. cereus. $^{3}$

Penelitian tentang khasiat madu pada zaman modern ini telah berkembang dengan cepat dan tidak terbatas pada pengobatan luka, madu juga digunakan untuk kontrol gula darah pasien diabetes, antioksidasi, mencegah radang lapisan luar disekitar mulut pada pengobatan sinar laser pasien kanker, mengobati radang saluran cerna, serta sebagai bahan produk kecantikan, rambut dan kulit. ${ }^{4}$ Aktivitas antibakteri madu telah dikenal sejak tahun 1999 oleh Cooper, Mohan dan Harding mengenai efek antibakteri. Salah satu penelitian pada saat ini adalah mengetahui efek madu terhadap Staphylococcus aureus (S.aureus) terutama pada madu Manuka yang merupakan salah satu jenis madu monoflora. Penelitian lain efek madu hutan dari Ciburial Bandung yang merupakan salah satu jenis madu multiflora terhadap $S$ aureus. ${ }^{5}$ Madu juga dapat mencegah serta sebagai kontrol infeksi terhadap Staphylococcus koagulase-negatif, Pseudomonas aeruginosae, Enterococcus $s p .^{6}$ Penelitian lain juga telah dilakukan mengenai uji aktivitas madu terhadap pertumbuhan Streptococcus mutans dengan 732konsentrasi 6,25\%. ${ }^{7}$

Bakteri Pseudomonas aeruginosae merupakan salah satu bakteri Gram negatif, aerob, dan bergerak dengan menggunakan flagel, dan merupakan bakteri oportunistik. Infeksi $P$. aeruginosae menimbulkan penyakit di berbagai jaringan antara lain pada saluran 
pernapasan, mata, saluran kemih, dan kulit. ${ }^{8}$ Selama ini pengobatan terhadap infeksi $P$. aeruginosae menggunakan antibiotik golongan penisilin, golongan sefalosporin, golongan aminoglikosida dan golongan fluorokuinolon. Berdasarkan laporan European Epic Study P. aeruginosa telah mengalami resisten terhadap beberapa antibiotik : gentamisin (46\%), imipenem (21\%), seftazidim (27\%), siprofloksasin (26\%), dan ureidopenisilin (37\%) .

Bakteri lain yang menimbulkan penyakit infeksi pada luka bakar adalah Staphylococcus aureus merupakan bakteri Gram positif, bulat, tersusun dalam rangkaian tak beraturan seperti anggur, mudah tumbuh dalam berbagai perbenihan dan mempunyai metabolisme aktif, serta menghasilkan pigmen yang bervariasi dari warna putih sampai kuning tua. Staphylococcus aureus dapat menyebabkan pernanahan, abses, dan lain-lain. ${ }^{10}$ Pada saat ini sekitar $40 \%$ dari bakteri S. aureus yang dapat diisolasi di rumah sakit, bakteri ini banyak resisten terhadap berbagai jenis antibiotik, tetapi beberapa masih sensitif terhadap Vankomisin, Clindamycin, Trimetoprim-sulfametoksazol, Gentamisin. Salah satu jenis Staphylococcus aureus yang telah resisten terhadap antibiotika adalah Staphylococcus aureus Resisten Metisilin (MRSA). Bakteri MRSA telah menyebar luas sebagai patogen dalam bentuk sekumpulan bakteri, selain resisten terhadap metisilin MRSA juga kini telah resisten terhadap penisilin, oxasilin, dan eritromisin. ${ }^{11}$ Oleh karena itu bakteri ini banyak ditemukan resisten di rumah sakit, ssehingga biaya pengobatan dan status kondisi penyakit pasien akan lebih tinggi. Maka salah satu alternatif pengobatan infeksi luka bakar selain dengan antibiotik yaitu yang berasal dari bahan alam., bakteri ini termasuk bakteri Gram positif yang menyebabkan penyakit penting pada manusia yang berkisar dari infeksi kulit permukaan yang ringan hingga penyakit sistemik yang mengancam hidup. Infeksi khasnya bermula di tenggorokan atau kulit. Infeksi ringan Streptococcus pyogenes termasuk faringitis (radang tenggorokan) dan infeksi kulit setempat (impetigo). Ensipelar dam seluliitis dicirikan dengan pertumbuhan dan penyebaran samping Streptococcus pyogenes dilapisan dalam kulit. ${ }^{12}$

Beberapa uji kepekaan madu terhadap aktivitas antibakteri secara in vitro dapat dilakukan dengan beberapa metode, yaitu metode difusi dengan: cakram, parit, dan lubang, semetara metode yang lain adalah metode dilusi yang terdiri dari dilusi padat dan dilusi cair. ${ }^{13}$

Berdasarkan uraian tersebut diatas, maka perlu dilakukan penelitian untuk menguji secara in vitro efektivitas antibakteri madu terhadap pertumbuhan Staphylococcus aureus dan Pseudomonas aeruginosae dengan metode disc diffusion. Dalam penelitian ini digunakan madu hutan Sumbawa Apis dorsata (Merk UKMWAY).

\section{METODOLOGI PENELITIAN Desain Penelitian}

Penelitian ini merupakan penelitian ekperimental laboratorik melalui metode disc diffusion untuk uji efektifitas antibakteri madu terhadap pertumbuhan bakteri Staphylococcus aureus dan Pseudomonas aeruginosae dengan metode difusi sumuran.

\section{Waktu dan Tempat Penelitian}

Penelitian ini akan dilakukan pada Bulan Mei 2013 sampai Oktober 2013 di Laboratorium Mikrobiologi Fakultas Kedokteran dan Ilmu Kesehatan UIN Syarif Hidayatullah Jakarta.

\section{Bahan yang diuji}

Madu Hutan Sumbawa (Apis dorsata) merk UKMWAY dengan berbagai konsentrasi. 


\section{Sampel Penelitian}

Bakteri Staphylococcus aureus dan Pseudomonas aeruginosae pada Nutrient Agar (NA).

\section{Identifikasi Variabel \\ Variabel Bebas}

Madu Hutan Sumbawa (Apis dorsata) merk UKMWAY dengan berbagai konsentrasi.

\section{Variabel Terikat}

Pertumbuhan Staphylococcus aureus dan Pseudomonas aeruginosae.

\section{Cara Kerja Penelitian}

Cara kerja penelitian ini sebagai berikut :

1. Pembuatan Konsentrasi Madu

Pembuatan Stok konsentrasi madu yang akan divariasikan adalah mulai dari $0 \%$ (kontrol), $10^{6} \mathrm{ppm}, 5 \times 10^{6} \mathrm{ppm}, 10^{7} \mathrm{ppm}$, $10^{8} \mathrm{ppm}$ dan antibiotik Amoksilin sebagai kontrol positif, ssehingga seluruhnya berjumlah 5 variabel, dilakukan secara triplo.

2. Uji Efektivitas Madu terhadap Pertumbuhan Bakteri Staphylococcus aureus dan Psedomonas aeruginosae. Memasukkan nutrien agar ke dalam cawan petri sebanyak kurang lebih $10 \mathrm{ml}$ diberi suspensi bakteri sebanyak kurang lebih $2 \mathrm{ml}$ dan diratakan ke dalam cawan petri dengan metode pour plate dan digoyangkan dengan vorteks. Media yang sudah di inokulasikan kuman tunggu beberapa menit hingga kering. Media yang sudah di inokulasikan kuman pada media Mueller Hinton Agar (MHA), kemudian dibuat beberapa lubang pada media MHA sebanyak sesuai dengan jumlah konsentrasi, lalu diinkubasi pada suhu $37^{\circ} \mathrm{C}$ selama 24 jam, keesokan harinya diukur diameter zona terang (clear zone) dengan menggunakan penggaris.

\section{HASIL DAN PEMBAHASAN}

1. Uji Efektivitas Larutan Madu Terhadap Pertumbuhan Kuman Staphylococcus aureus

Penelitian uji efektivitas madu sebagai antibakteri terhadap Staphylococcus aureus ini diuji secara in vitro dengan mengukur zona hambat pada media agar yang dibuat sumur diisi madu dan pengukurannya menggunakan satuan millimeter.

Tabel 1. Hasil Pengamatan Uji Efektivitas Madu Terhadap Staphylococcus sureus

\begin{tabular}{|c|c|c|c|c|c|c|c|}
\hline \multirow{2}{*}{$\begin{array}{c}\text { Per } \\
\text { cob } \\
\text { aan }\end{array}$} & \multicolumn{7}{|c|}{$\begin{array}{c}\text { Zona Hambat Madu/millimeter \& } \\
\text { Konsentrasi Madu (ppm) }\end{array}$} \\
\hline 1 & 0 & 6 & 11 & 12 & 16 & 26 & 0 \\
\hline 2 & 0 & 7 & 10 & 12 & 18 & 23 & 0 \\
\hline $\begin{array}{c}\text { Tot } \\
\text { al }\end{array}$ & 0 & 13 & 21 & 24 & 34 & 49 & 0 \\
\hline $\begin{array}{c}\text { Mea } \\
\text { n }\end{array}$ & 0 & 6,5 & 10,5 & 12 & 17 & 24,5 & 0 \\
\hline
\end{tabular}

Berdasarkan hasil penelitian didapatkan hasil uji aktivitas konsentrasi madu terhadap Staphylococcus aureus, didapatkan diameter zona hambat paling rendah pada konsentrasi madu $10^{6} \mathrm{ppm}$ yaitu 6,5 $\mathrm{mm}$. Dari hasil klasifikasi menurut Green Wood (1995) bahwa kriteria daya hambat bakteri dengan konsentrasi tidak termasuk kategori, hal ini disebabkan zona hambat bakteri tersebut adalah kurang dari $10 \mathrm{~mm}^{.14}$

Pada penelitian ini dari hasil pengukuran zona hambat pada konsentrasi madu terhadap Staphylococcus aureus termasuk klasifikasi kriteria daya hambat bakteri yang kategori lemah yaitu pada konsentrasi $5 \times 10^{6} \mathrm{ppm}$ dan $10^{7} \mathrm{ppm}$ yaitu diameter sebesar 10,5 $\mathrm{mm}$ dan $12 \mathrm{~mm}$. Hal ini disebabkan pada uji efektivitas kategori lemah termasuk dalam ukuran diameter 10$15 \mathrm{~mm} .{ }^{14}$ Pada penelitian ini juga dari hasil pengukuran zona hambat pada konsentrasi madu terhadap Staphylococcus aureus termasuk klasifikasi kriteria daya hambat 
bakteri yang kategori sedang yaitu pada konsentrasi $10^{8}$ ppm dengan diameter sebesar $17 \mathrm{~mm}$. Hal ini disebabkan pada uji efektivitas kategori lemah termasuk dalam ukuran diameter $17-20 \mathrm{~mm}^{14}$

Penelitian madu juga dilakukan oleh Suci Lucyana (2012) yang menyatakan bahwa daya hambat madu terhadap pertumbuhan Staphylococcus aureus terdapat pada konsentrasi $40 \%, 80 \%$, dan $100 \%$ dengan ukuran zona hambat $1,75 \mathrm{~mm}$, 9,25 mm, dan $11,25 \mathrm{~mm} .{ }^{16}$ Penelitian ini dilakukan dengan membandingkan larutan madu kapuk dan madu hutan terhadap Staphylococcus aureus dengan metode difusi. Perbedaannya dengan penelitian ini dengan penelitian Suci Lucyani adalah penelitian ini melakukan uji aktivitas madu antara bakteri Staphylococcus aureus dan Pseudomonas aeruginosae dan konsentrasi madu yang digunakan.

Penelitian lain juga dilakukan oleh Hendri Wasito, Sani Ega dan Yani Lukmayani (2008), penelitian in menggunakan sampel jenis madu hutan dari wilayah Ciburial Bandung yang termasuk jenis multiflora. Berdasarkan hasil penelitian ini ternyata memiliki aktivitas antibakteri terhadap $S$. aureus, media yang digunakan Vogel Jhonson Agar dengan metode difusi agar sumuran dengan kedalaman yang sama. Konsentrasi madu yang di gunakan adalah $1 \%, 2,5 \%, 5 \%, 10 \%, 25 \%$, dan $50 \%$. Hasil uji aktivitas madu menghasilkan zona hambat pada media pertumbuhan dimulai madu yang digunakan dengan konsentrasi $5 \%, 10 \%, 25 \%$ dan $50 \%$ menuunjukan zona hambat sebesar $22,8 \mathrm{~mm}, 26,90 \mathrm{~mm}, 28,80$ $\mathrm{mm}$ dan $28,7 \mathrm{~mm}$.

\section{Uji Efektivitas Larutan madu Terhadap pertumbuhan Pseudomonas aeruginosae}

Penelitian uji efektivitas madu sebagai antibakteri terhadap Pseudomonas aeruginosae ini diuji secara in vitro dengan mengukur zona hambat pada media agar yang dibuat sumuran pada media, diisi larutan madu dan pengukurannya menggunakan satuan millimeter.

Tabel 2.Hasil Pengamatan Uji Efektivitas Madu Terhadap P. Aeruginosae

\begin{tabular}{|c|c|c|c|c|c|c|c|}
\hline \multirow{2}{*}{$\begin{array}{c}\text { Perco } \\
\text { baan }\end{array}$} & \multicolumn{7}{|c|}{ Zona Hambat Madu/millimeter \& } \\
\cline { 2 - 8 } & $\mathbf{1 0}^{5}$ & $\mathbf{1 0}^{\mathbf{6}}$ & $\mathbf{5 x 1 0}^{\mathbf{6}}$ & $\mathbf{1 0}^{\mathbf{7}}$ & $\mathbf{1 0}^{\mathbf{8}}$ & $\mathbf{K}(+)$ & $\mathbf{K}(-)$ \\
\hline 1 & 0 & 6 & 10 & 11 & 12 & 19 & 0 \\
\hline 2 & 0 & 6 & 7 & 8 & 9 & 19 & 0 \\
\hline Total & 0 & 12 & 17 & 19 & 21 & 38 & 0 \\
\hline Mean & 0 & 6 & 8,5 & 9,5 & 10,5 & 19 & 0 \\
\hline
\end{tabular}

Berdasarkan hasil penelitian didapatkan hasil uji aktivitas konsentrasi madu terhadap $P$. aeruginosae, didapatkan diameter zona hambat paling rendah pada konsentrasi madu $10^{6} \mathrm{ppm}, 5 \times 10^{6} \mathrm{ppm}, 10^{7}$ ppm yaitu $6 \mathrm{~mm}, 8,5 \mathrm{~mm}$, dan 9,5 mm. Dari hasil klasifikasi kriteria daya hambat bakteri ke-3 konsentrasi tidak termasuk kategori, hal ini disebabkan zona hambat kurang dari 10 mm. ${ }^{14}$

Pada penelitian ini dari hasil pengukuran zona hambat pada konsentrasi madu terhadap Staphylococcus aureus termasuk klasifikasi kriteria daya hambat bakteri yang kategori lemah yaitu pada konsentrasi $10^{8} \mathrm{ppm}$ yaitu $10,5 \mathrm{~mm}$. Hal ini disebabkan pada uji efektivitas kategori rendah termasuk dalam ukuran $10-15 \mathrm{~mm} .{ }^{14}$

Penelitian ini juga dilakukan oleh Suci Lucyana (2012) yang menyatakan bahwa daya hambat madu terhadap pertumbuhan Staphylococcus aureus terdapat pada konsentrasi 40\%, 80\%, dan $100 \%$ dengan ukuran zona hambat $1,75 \mathrm{~mm}$, $9,25 \mathrm{~mm}$, dan $11,25 \mathrm{~mm}$. Penelitian ini dilakukan dengan membandingkan larutan madu kapuk dan madu hutan terhadap Staphylococcus aureus dengan metode difusi. Perbedaannya dengan penelitian ini dengan penelitian Suci Lucyani adalah 
penelitian ini melakukan uji aktivitas madu antara bakteri Staphylococcus aureus dan Pseudomonas aeruginosae dan konsentrasi madu yang digunakan.

Penelitian lain juga dilakukan oleh Hendri Wasito, Sani Ega dan Yani Lukmayani (2008), penelitian in menggunakan sampel jenis madu hutan dari wilayah Ciburial Bandung yang termasuk jenis multiflora. Berdasarkan hasil penelitian ini ternyata memiliki aktivitas antibakteri terhadap $S$. aureus, media yang digunakan Vogel Jhonson Agar dengan metode difusi agar sumuran dengan kedalaman yang sama. Konsentrasi madu yang di gunakan adalah $1 \%, 2,5 \%, 5 \%, 10 \%, 25 \%$, dan 50\%. Hasil uji aktivitas madu menghasilkan zona hambat pada media pertumbuhan dimulai dengan konsentrasi 5\%, 10\%, 25\% dan 50\% menunjukkan zona hambat sebesar $22,8 \mathrm{~mm}$, $26,90 \mathrm{~mm}, 28,80 \mathrm{~mm}$ dan $28,7 \mathrm{~mm}$.

\section{Perbandingan Uji Efektivitas Larutan Madu Terhadap Pertumbuhan Staphylococcus aureus dan Pseudomonas aeruginosae Dengan Metode Difusi Sumur}

Berdasarkan hasil pengamatan zona hambat antara kuman Staphylococcus aureus (Gram positif) dan Pseudomonas aeruginosae (Gram negatif), zona hambat bakteri Gram positif lebih besar dibandingkan bakteri Gram negatif, disebabkan terdapat perbedaaan struktur antara bakteri Gram positif dengan bakteri Gram negatif, struktur dinding sel bakteri Gram negatif terdiri dari tiga lapis (multi), kandungan lipid pada dinding sel lebih tinggi (11-22\%), hal inilah yang mungkin dapat mempengaruhi penetrasi dari zat aktif ekstrak menjadi lebih sulit pada bakteri Gram negatif, ssehingga pertumbuhannya dihambat tidak sebesar bakteri Gram positif. Selain itu persentase zat antibakteri juga ikut mempengaruhi. ${ }^{16}$ Hasil penelitian uji efektivitas larutan madu ternyata dapat menghambat bakteri Staphylococcus aureus dan Pseudomonas aeruginosae dikarenakan pada madu terdapat kandungan hidrogen peroksida, $\mathrm{pH}$ yang rendah dan aktivitas air yang rendah. ${ }^{17}$

Efek antibakteri ini kemungkinan disebabkan oleh beberapa faktor antibakteri yang terdapat didalamnya. Yang pertama adalah kandungan glukosa dan fruktosa madu yang sangat tinggi dengan demikian menyebabkan larutan sangat hipertonis bila dibandingkan dengan lingkungan di dalam tubuh bakteri, sifat ini akan menyebabkan lisisnya bakteri akibat dehidrasi yang berat karena efek osmosis. ${ }^{18}$ Faktor yang kedua adalah $\mathrm{pH}$ madu yang bersifat asam berkisar antara 3,2 - 4,5 ssehingga akan menghambat metabolisme bakteri Gram negatif, dengan terhambatnya metabolisme bakteri menyebabkan bakteri mudah mengalami lisis, ssehingga akhirnya dapat menghambat pertumbuhan bakteri. Sedangkan untuk tumbuh dan berkembang biak secara optimum ke-2 bakteri membutuhkan $\mathrm{pH}$ 6-8. ${ }^{18}$ Faktor yang ketiga adalah adanya kandungan hidrogen peroksida yang bersifat sitotoksik bagi sel bakteri. Proses antimikroba dari hidrogen peroksidase karena kemampuan pengoksidasian serta formasi radikal bebas hidroksil yang lebih toksik dari peroksida, ssehingga memudahkan terjadinya kerusakan sel-sel bakteri. ${ }^{18}$ Faktor yang lain adalah karena kandungan nutrisi dan gizi yang terdapat dalam madu ssehingga mampu meningkatkan imunitas tubuh apabila digunakan secara in vivo. Madu banyak mengandung vitamin $\mathrm{B}_{2}, \mathrm{~B}_{3}, \mathrm{~B}_{6}, \mathrm{C}, \mathrm{K}$, karoten, biotin, dan lain-lain; dimana bahan-bahan tersebut dapat meningkatkan ketahanan tubuh terhadap infeksi bakteri. ${ }^{18}$ Faktor-faktor antimikroba tersebut tidak menutup kemungkinan juga diperkuat oleh faktor-faktor lain dalam madu yang mendukung sifat antimikroba madu.

Menurut Ika Puspitasari (2007) adanya zona hambat pada larutan madu terhadap ke-2 bakteri disebabkan karena komposisi lengkap dari madu, diantaranya konsentrasi gula yang tinggi, keasaman dan adanya pollen. Sedangnkan menurut Mundo et.al (2004) ada beberapa faktor yang menyebabkan madu 
mempunyai aktivitas antibakteri, seperti keasaman, tekanan osmotik, dan hidrogen peroksida. Komponen tambahan lain pada madu misalnya asam aromatik dan kandungan fenol yang berperan dalam aktivitas antibakteri. Faktor lain yang ikut berperan adalah faktor non peroksida dalam aktivitas antibakteri madu. Komponen lain seperti lisozim, asam fenolik dan flavonoid juga terdapat madu. Komponen fenolik lainnya yang terdapat pada nektar juga mempunyai aktivitas antioksidan, aktivitas antioksidan ini berperan dalam menghambat bakteri Gram positif dan Gram negatif. Pada madu terkandung konsentrasi gula yang tinggi yang berperan sebagai antibakteri yang berkaitan dengan banyaknya penggunaan larutan madu untuk penanganan luka akibat luka bakar. Penanganan luka ini berhubungan dengan kadar gula yang tinggi pada madu menimbulkan viskositas yang tinggi ssehingga jugaa sebagai barier infeksi pada luka, selain itu kadar gula yang tinggi menjamin suplai gula untuk lekosit dan makrofag. ${ }^{19}$ Menurut Molan (2001) menyatakan bahwa dalam madu terkandung hidrogen peroksida yang dihasilkan oleh glukosa oksidase madu yang merupakan komponen penghambat melawan bakteri atau sebagai antibakteri. Zat glukosa oksidae dikeluarkan dari kelenjar hipofaring lebah ke dalam nektar untuk membantu pembentukan madu dari nektar. Kuman Staphylococcus aureus dan Pseudomonas aeruginosae merupakan bakteri yang menghasilkan katalase yang akan mengeliminasi hidrogen peroksida, ke-2 bakteri ini katalase aktif dengan konsentrasi hidrogen peroksida yang tinggi. Oleh karena itu kasus penghambatan yang dihasilkan oleh madu terhadap ke-2 bakteri ini yaitu Staphylococcus aureus dan Pseudomonas aeruginosae dapat disebabkan adanya hidrogen peroksida. Faktor lain yang lebih berperan adalah keasaman, efek osmotik, dan senyawa fenol dalam madu. Berdasarkan hasil penelitian ternyata larutan madu dapat menghambat bakteri Staphylococcus aureus dan Pseudomonas aeruginosae, dikarenakan madu mengandung senyawa flavonoid dan alkaloid yang berfungsi sebagai bahan obat-obatan. Mekanisme reaksi ini menunjukkan bahwa interaksi antara derivat fenolik dengan protein pada membran sel yang menyebabkan rusaknya struktur membran sel. Senyawa fenol masuk ke dalam sel bakteri melewati dinding sel bakteri dan membran sitoplasma, ternyata senyawa fenol di dalam sel bakteri mengakibatkan penggumpalan (denaturasi) protein penyusun protoplasma ssehingga dalam keadaan demikian metabolisme bakteri menjadi inaktif dan pertumbuhan bakteri menjadi terhambat. ${ }^{20}$ Berdasarkan hasil uji larutan madu terhadap ke-2 bakteri tersebut, maka ternyata madu efektif sebagai antibakteri terhadap bakteri Staphylococcus aureus dan Pseudomonas aeruginosae ada pengaruh berbagai konsentrasi madu terhadap pertumbuhan ke2 bakteri tersebut dimana semakin tinggi konsentrasi madu semakin besar konsentrasi zona hambat bakteri. Dari penelitian ini dapat diketahui bahwa madu memiliki peluang untuk digunakan sebagai pengobatan infeksi yang disebabkan oleh bakteri Staphylococcus aureus dan Pseudomonas aeruginosae khususnya penyakit infeksi luka bakar akibat infeksi nosokomial. Mekanisme madu dalam penyembuhan infeksi ini selain karena sifat antimikrobanya juga karena kemampuannya dalam meningkatkan stamina tubuh ssehingga dapat membantu meringankan penderita. Berdasarkan hasil penelitian ternyata larutan madu dapat menghambat bakteri Staphylococcus aureus dan Pseudomonas aeruginosae, dikarenakan madu mengandung senyawa flavonoid dan alkaloid yang berfungsi sebagai bahan obatobatan. Mekanisme reaksi ini menunjukkan bahwa interaksi antara derivat fenolik dengan protein pada membran sel yang menyebabkan rusaknya struktur membran sel. Senyawa fenol masuk ke dalam sel 
bakteri melewati dinding sel bakteri dan membran sitoplasma, ternyata senyawa fenol di dalam sel bakteri mengakibatkan penggumpalan (denaturasi) protein penyusun protoplasma sehingga dalam keadaan demikian metabolisme bakteri menjadi inaktif dan pertumbuhan bakteri menjadi terhambat. ${ }^{20}$

\section{KESIMPULAN DAN SARAN}

Kesimpulan yang dapat diambil dari penelitian ini adalah :

1. Uji efektivitas larutan madu terhadap $S$. aureus pada konsentrasi $10^{6} \mathrm{ppm}, 5 \times 10^{6}$ ppm, $10^{7} \mathrm{ppm}$, dan $10^{8} \mathrm{ppm}$ didapatkan zona hambat dengan rata-rata diameter hambatan sebesar $6,5 \mathrm{~mm}, 10,5 \mathrm{~mm}, 12$ $\mathrm{mm}$, dan 14,7 mm. Berdasarkan hasil penelitian didapatkan konsentrasi larutan madu telah dapat menghambat pertumbuhan bakteri $S$. aureus dengan kategori hambatan lemah.

2. Uji efektivitas larutan madu terhadap $P$. aeruginosae pada konsentrasi $10^{6} \mathrm{ppm}$, $5 \times 10^{6} \mathrm{ppm}$, dan $10^{7} \mathrm{ppm}$ didapatkan zona hambat dengan rata-rata sebesar $6 \mathrm{~mm}$, $8,5 \mathrm{~mm}$, dan $9,5 \mathrm{~mm}$, diameter zona hambat tersebut tidak termasuk dalam kategori (rendah). Sedangkan konsentrasi $10^{8} \mathrm{ppm}$ didapatkan zona hambat 10.5 $\mathrm{mm}$, berdasarkan hasil dari zona hambat tersebut maka uji efektivitas termasuk dalam kategori lemah.

3. Perbandingan Uji efektivitas larutan madu terhadap laju pertumbuhan kuman Sthapylococcus aureus dan Pseudomonas aeruginosae ternyata efektivitas larutan madu lebih efektif terhadap $S$. aureus daripada $P$. aeruginosae walaupun perbedaannya tidak signifikan.

\section{DAFTAR PUSTAKA}

1. WHO. Infectious disease are the biggest killer of the young; 1999. Avalaible from http://www.who.int/infectous-disease- report/index-rpt99.htm. Accessed Juli 12, 2009.

2. Vardi A, Barzilay Z, Linder N, Cohen HA, Paret G, Barzilai A. Local application of Honey for Treatment of Neonatal Postoperative Wound Infection.; 1998. Available from http://www.ncbi.nlm.nih.gov/pubmed/96 28301. Accessed Mei 17, 2009.

3. Hotnida $\mathrm{CH}$. Pengaruh metode penurunan kadar air, suhu dan lama penyimpanan terhadap kualitas madu randu (thesis). Jakarta: Fakultas Kedokteran Universitas Indonesia; 1998.

4. Aiman BAF. Pengobatan dan Penyembuhan menurut wahyu Nabi, Jakarta: Pustaka As-sabil; 2004.

5. Hendri W, Sani EP \& Yani L. Uji Akivitas Antimikroba Madu Terhadap Mikroba Staphylococcus aureus; 2008. Available from: http://hendriapt. wordpress.com/2008/11/14/uji-aktivitasantibacteri-madu-terhadap-bakteristaphylococcus-aureus. Accessed Nov 2008.

6. French VM, Cooper RA and Molan PC. The Antibacterial of Honey against coagulae-negative Staphylococci. Oxforddjournals (serial on the internet). 2005. Available from: http://jac.oxford djournals.org/cgj/content/full/56/1/228. Accessed March 2005.

7. Lasmayanty.Potensi Antibakteri Propolis Lebah Madu Trigona Terhadap bakteri Kariogenik (Streptococcus mutans). Program Studi Biokimia MIPA IPB Bogor. 2007.

8. Todar Kenneth.Textbook of bacteriology: Pseudomonas aeruginosa. University of Wisconsin-Madison Department of Bacteriology. 2004.

9. Dwiprahasto I. Kebijakan untuk meminimlakan Resiko Terjadinya Resistensi Bakteri di Unit Perawatan Intensif RS.JMPK. 2005; 8(4) : 177-178. 
10. Jawetz E, Melnick JL \& EA Adelber. Mikrobiologi Kedokteran. Jakarta: Salemba Medika. 2006.

11. Karchmer, A.W. From theory to practice: resistance in Staphylococcus aureus and new treatments. Clin. Microbiol. Infect. 2006; 12 (8): 15-21.

12. Jawetz E, Melnick JL, and Adelber EA . Mikrobiologi Kedokteran Edisi 20. Penerjemah: Edi Nugroho \& RF Maulany, Penerbit Buku Kedokteran EGC, Jakarta. 2006; 211-215.

13. Pratiwi, Silvia T. Mikrobiologi Farmasi, Jakarta, Erlangga; 2010.

14. Greenwood. Antibiotics Susceptibility (Sensitivity) Test, Antimicrobial and Chemotheraphy. USA : Mc Graw Hill Company. 1995.

15. Jawetz E., Melnick JL and EA Adelber. Medical Microbiology, Edisi ke-22. Penerjemah: Edi Nugroho \& RF Maulany. Penerbit Buku Kedokteran EGC: Jakarta. 2001; 229-231.

16. Puspitasari I. Rahasia Sehat Madu. Yogyakarta: B-First (PT.Bentang Pustaka). 2007.

17. Suci L, Uji Aktivitas Antimikroba Larutan Madu Kapuk dan Madu Hutan Terhadap Staphylococcus aureus Secara In vitro, Skripsi FKUPN "Veteran" Jakarta. 2010.

18. Suriawiria U. Pengantar Mikrobiologi Umum. Angkasa Bandung. 2000.

19. Molan PC. The Antibacterial Activity of Honey: The Nature of the Antibacterial Activity, Bee World. 1992; 73(1) : 5-8.

20. Dwidjoseputro:Dasar-Dasar Mikrobiologi. Djambatan, Jakarta. 2005. 